\title{
Agata Stasik
}

agata.stasik@amu.edu.pl

Instytut Etnologii i Antropologii Kulturowej

Uniwersytet im. Adama Mickiewicza w Poznaniu

\section{GRANICE NIELEGALNOŚCI. ŚLIWOWICA ŁĄCKA W PERSPEKTYWIE ANTROPOLOGICZNEJ}

\section{Limits of illegality. Slivovitz in the anthropological perspective}

Streszczenie: Artykuł jest oparty na etnograficznych badaniach terenowych i dotyczy produkcji oraz dystrybucji śliwowicy łąckiej, a także sieci powiązań lokalnej gospodarki owocowej ze strukturami państwa. Autorka opisuje sposoby i motywacje stojące za decyzjami o wykorzystaniu śliwek z łąckich sadów przez poszczególnych aktorów społecznych. Odpowiada również na pytanie, jak to, co uznawane za nieformalne/nielegalne przenika się w Łącku z formalnym/legalnym. Tym samym postuluje, by praktyki w świetle prawa uznawane za nielegalne, w perspektywie antropologicznej rozpatrywać $\mathrm{w}$ dynamicznych kategoriach dialektyki legalnego z nielegalnym.

Słowa kluczowe: śliwowica łącka, alkohol, legalność, nielegalność, prawo, ekonomia nieformalna.

Abstract: The article is based on ethnographic fieldwork and discusses the production and distribution of the Slivovitz, as well as the links between the local fruit economy and the state structures. The author shows how and why certain social actors decide to use the plums from the local orchards. She also answers how the informal / illegal intermingles with formal / legal in Łącko. She proposes considering the illegal in a more dynamic category of dialectics between the legal and the illicit.

Keywords: Slivovitz, alcohol, legality, illegality, law, informal economy. 


\section{Wprowadzenie}

Na początku lat dziewięćdziesiątych XX wieku wojewódzki urząd konserwatora zabytków w Nowym Sączu uznał śliwowicę łącką za niematerialne dobro kultury. W 2005 roku wpisano ją na listę produktów tradycyjnych Ministerstwa Rolnictwa i Rozwoju Wsi. Kilka lat później Stowarzyszenie Łącka Droga Owocowa w Urzędzie Patentowym Rzeczpospolitej Polskiej zastrzegło wspólny znak towarowy dla nazwy „Śliwowica Łącka” oraz zwrotu „daje krzepę, krasi lica [nasza łącka Śliwowica]", który znajduje się na etykietach. Na mocy porozumienia zawartego pomiędzy gminą a stowarzyszeniem strony zobowiązały się do realizacji działań mających na celu rozpowszechnianie oraz promowanie produktu regionalnego (tradycyjnego), jakim jest śliwowica łącka, a także wspieranie wszelkich inicjatyw $\mathrm{w}$ tym zakresie. Jednocześnie ustawa $\mathrm{z}$ dnia 2 marca 2001 r. o wyrobie spirytusu, wyrobie i rozlewie wyrobów spirytusowych oraz wytwarzaniu wyrobów tytoniowych (Dz.U. $2001 \mathrm{nr} 31$ poz. 353) zakazuje produkcji destylatów alkoholowych. Każdy, kto bez wymaganego wpisu do właściwego rejestru produkuje, skaża, oczyszcza lub odwadnia alkohol etylowy (art. 12a ust.1) podlega karze grzywny, ograniczenia lub pozbawienia wolności do roku.

Legalna produkcja śliwowicy w Polsce jest możliwa wówczas, gdy przedsiębiorca zostanie wpisany do rejestru podmiotów wykonujących działalność w zakresie wyrobu lub rozlewu napojów spirytusowych oraz do rejestru podmiotów wykonujących działalność w zakresie wyrobu i przetwarzania alkoholu etylowego. Ponadto, producent zobligowany jest do spełnienia szeregu wymogów formalnych - uzyskania odpowiedniej koncesji, wdrożenia systemu kontroli jakości produkcji oraz uiszczenia podatku akcyzowego. Oznacza to, że dla większości producentów legalizacja działalności byłaby niezwykle wymagającym przedsięwzięciem oraz niekorzystnie wpłynęłyby na ostateczną cenę produktu. $\mathrm{Z}$ tego też względu legalna śliwowica łącka dostępna jest jedynie w sklepach (stacjonarnych i internetowym) należących do lokalnej przetwórni soków owocowych.

Niniejszy artykuł poświęcony jest produkcji i dystrybucji śliwowicy łąckiej oraz sieciom powiązań lokalnej gospodarki owocowej ze strukturami państwa. Przedstawię, w jaki sposób państwo utrzymuje nieformalne praktyki ekonomiczne oraz zwrócę uwagę na niestabilny charakter kategorii legalności i nielegalności. Tym samym postaram się odpowiedzieć 
Granice nielegalności. Śliwowica łącka w perspektywie antropologicznej

na pytanie, w jaki sposób to, co uznawane za nieformalne/nielegalne przenika się w Łącku z formalnym/legalnym.

\section{Badania}

Latem 2015 roku zdecydowałam pojechać w miejsce, gdzie, jak byłam przekonana, alkohol musi odgrywać niebagatelną rolę w procesie utożsamiania i bycia utożsamianym (Ardener 1992). W miejsce, które znane jest przede wszystkim z produkcji śliwowicy łąckiej oraz jej nielegalności. Byłam przekonana, że uda mi się dotrzeć do ludzi, którzy wokół śliwowicy organizują swoje życie i dla których - jak sobie wyobrażałam - będzie to coś niezwykle ważnego. Bardzo szybko zostałam zmuszona do weryfikacji założeń, co przez wielu badaczy uważane jest za nieodłączny element antropologii (Favret-Saada 2012: 32). Po pierwsze, teren skierował moją uwagę $\mathrm{w}$ stronę ekonomii i polityki, które dotychczas znajdowały się na marginesie moich zainteresowań. Po drugie zaś, przekonałam się, że produkt regionalny nie musi odgrywać kluczowej roli symbolicznej w codziennych praktykach społeczności lokalnej.

Artykuł oparty jest na materiale etnograficznym zebranym podczas kilkutygodniowych badań terenowych w latach 2015 i 2016. Badania polegały na nieustrukturyzowanych i w większości przypadków nierejestrowanych rozmowach oraz wywiadach z osobami publicznymi. Jednak najważniejsze były wspólna praca, domowe posiłki oraz towarzyszenie w różnych, często niespodziewanych sytuacjach. Większość mojej pracy terenowej polegała przede wszystkim na udziale w codziennych praktykach, pozornie niezwiązanych z przedmiotem badań. To dzięki temu byłam w stanie, jak sądzę, wyjść poza opis etnograficzny i zmierzyć się $\mathrm{z}$ tematem teoretycznie, co jest o tyle trudne, że przynajmniej na gruncie polskiej antropologii brak opracowań dotyczących alkoholu.

$\mathrm{Z}$ uwagi na przedmiot badań od samego początku nastawiona byłam na ochronę osób, z którymi miałam współpracować. Ze względu na konsekwencje prawne, które mogłyby dosięgnąć moich znajomych i tych bardziej przypadkowych rozmówców, a także możliwe konsekwencje społeczne, postanowiłam, że każda z postaci, która pojawi się w niniejszym artykule, pozostanie anonimowa. Jest to zadanie o tyle trudne, że śliwowica łącka to produkt utożsamiony z konkretnym miejscem na mapie, a więc niemożliwym było stworzenie fikcyjnej wsi z fikcyjnymi nazwiskami. 
Oznacza to, że opis osób, z którymi rozmawiałam i spędzałam czas jest ograniczony do minimum. Zasada anonimowości nie obejmuje jedynie osób publicznych.

\section{Produkcje}

Ze względu na panującą w sierpniu suszę, sadownictwo w dużej mierze ograniczało się do jeżdżenia $\mathrm{z}$ beczkami wypełnionymi wodą. Od kilku tygodni pan Jerzy zajmował się przede wszystkim nawadnianiem gleby. Początkowo, jak inni sadownicy tego dnia, twierdził, że nie znajdzie dla mnie pracy, bo obieranie śliw (czyli zbieranie owoców) przypada dopiero na koniec września. Jednak już kilka godzin później, oderwana od plotek i wyposażona w sekator, przycinałam niewielkie jabłonki w sadzie pana Jerzego, który z nieznanego mi powodu zmienił zdanie. Pracowałam kilka godzin dziennie, dostając wynagrodzenie w gotówce. Po każdym dniu pracy razem $\mathrm{z}$ panem Jerzym i Krzyśkiem, który również pracował w sadzie, zasiadaliśmy przy kuchennym stole. Żona lub synowa pana Jerzego przygotowywała dla nas kanapki, najczęściej z wędliną. Na stole pojawiały się również pomidory z cebulą, ogórki i herbata. Przez kilka kolejnych tygodni wykonywałam drobne prace w sadzie, najczęściej związane $\mathrm{z}$ jabłoniami, które dominują w łąckim krajobrazie. Niespodziewanie, któregoś dnia pan Jerzy zadzwonił z pytaniem, czy nie chcę zbierać śliwek na śliwowicę. Byłam zaskoczona, ponieważ jeszcze niedawno słyszałam, że ,śliwowica jest, owszem, ale nie u mnie. U nas to raczej tak dla siebie, przeciery do słoika".

Istnieją trzy dominujące sposoby produkcji śliwowicy. Wszystkie osoby, z którymi rozmawiałam, twierdziły, że śliwowicę pędzi każdy, kto posiada drzewa owocowe, niezależnie od ich ilości („wszyscy robią"). Jednocześnie jedynym producentem, którego wskazywano wprost był Krzysztof Maurer, właściciel lokalnej tłoczni soków owocowych. Produkcję okowit, jak sam nazywa sprzedawane przez siebie alkohole, rozpoczął w 2012 roku, a więc dopiero kilka lat po tym, jak śliwowica łącka została wpisana na ministerialną listę produktów tradycyjnych. Pozostali producenci pozostają anonimowi dla osób z zewnątrz (takich jak ja) - chyba, że w toku nawiązywania relacji dojdzie do przełamania dystansu i/lub stworzenia długotrwałej więzi. Jak twierdzi Maurer, 
Granice nielegalności. Śliwowica łącka w perspektywie antropologicznej

produkcja legalnej śliwowicy jest rodzajem fanaberii, na którą mógł sobie pozwolić tylko dlatego, że tłocznia soków stanowi zabezpieczenie finansowe w razie niepowodzenia. Ze względu na cenę alkohole Maurera niewątpliwie są towarem luksusowym - półlitrowa butelka śliwowicy kosztuje 117,99 złotych. Wysokie ceny są rezultatem zalegalizowania produkcji, wpływają jednocześnie na kształtowanie się potencjalnej grupy konsumentów.

Drugi sposób produkcji, najbardziej rozpowszechniony, choć w świetle prawa nielegalny, społecznie jest akceptowany. Oznacza to, że funkcjonuje rodzaj umowy społecznej, na mocy której bimbrownicy nie ponoszą odpowiedzialności karnej (a jeśli ponoszą, to dlatego, że w jakiś sposób naruszają warunki umowy). Producenci takiej śliwowicy nie rejestrują swoich wyrobów, nie płacą podatków i nie podlegają kontroli instytucji państwowych. Produkcja jest akceptowana lub tolerowana przez wielu aktorów społecznych (sąsiadów, rodzinę, a także policję czy władze gminy), a przynajmniej utrzymywany jest obojętny stosunek do tej działalności. Należy jednak pamiętać, że nastawienie władz ulegało zmianie i jeszcze w latach siedemdziesiątych regularnie urządzano „łapanki” na bimbrowników, którzy potrzebny do destylacji sprzęt chowali w okolicznych lasach. Po drugie, nawet obecnie tolerancja władz ma swoje granice. Wielokrotnie wspominano przy mnie o Święcie Śliwowicy. Przez kilka pierwszych lat jednym z punktów programu był pokaz destylacji śliwowicy, a na stoiskach widoczne były butelki $\mathrm{z}$ alkoholem - wszystko odbywało się za zgodą lokalnych władz. Dzisiaj święto funkcjonuje pod zmienioną nazwą - Święto Owocobrania, a pokazu destylacji już nie znajdziemy w programie.

Trzeci sposób produkcji, o którym z racji kryminalnego charakteru wiem najmniej, polega na połączeniu spirytusu, często wątpliwej jakości, ze sztucznym aromatem śliwkowym (esencja smakowa lub tzw. zaprawka). Gotowy produkt można kupić już za kilkanaście złotych. Alkohol przelewany jest do butelek posiadających etykiety z zastrzeżonym hasłem, które można nie tylko samodzielnie wydrukować w hurtowych ilościach (wzory są dostępne w Internecie), ale również kupić na terenie gminy. W lokalnych mediach regularnie pojawiają się informacje na temat aresztowań osób zaangażowanych w tego rodzaju działalność, która przez mieszkańców, sadowników i władze postrzegana jest jako szkodliwa. 


\section{Motywacje}

Rok później anomalie pogodowe dały o sobie znać po raz kolejny - tym razem pod postacią krótkich, choć niezwykle intensywnych burz gradowych. Grad ma to do siebie, że potrafi zniszczyć uprawę w ciągu zaledwie kilku minut. W sadzie pana Jerzego część mniejszych i słabszych owoców spadła na ziemię, kolejne zostały w różnym stopniu poobijane, zostały na nich ślady podobne do siniaków. Nawet jedna, niewielkich rozmiarów plamka może sprawić, że owoce nie zostaną kupione przez hurtowników czy Spółdzielnię Ogrodniczą Ziemi Sądeckiej, ponieważ wygląd owoców ma kluczowe znaczenie. Po burzy gradowej część owoców pana Jerzego nie nadawała się już do sprzedaży, co było dla niego poważnym problemem.

Istnieje jednak kilka możliwości, co zrobić z uszkodzonymi owocami, które nie spełniają kanonów piękna obowiązujących w dziale warzyw i owoców. Ze śliwek można zrobić powidła. Można je ususzyć i lekko podwędzić (w sadzie pana Jerzego stoi specjalne urządzenie przeznaczone do suszenia śliw, które co roku przy pomocy wiertła trzeba czyścić z lepkiego, śliwkowego osadu). Istnieje też trzecia możliwość, która polega na zapakowaniu śliw do dębowych beczek i odstawieniu ich na półtora miesiąca. Później zwartość beczki jest destylowana, ale alkohol ma tylko $30-40 \%$, więc trzeba odczekać i poddać alkohol ponownej destylacji. I to właśnie ta trzecia metoda wydaje się być najbardziej racjonalna z punktu widzenia sadowników (choć należy pamiętać, że nie każdy producent śliwowicy jest sadownikiem). Śliwki najlepiej pakować do beczek, bo jak twierdzi sąsiad pana Jerzego, ,jak śliwka po 80 groszy chodzi, to się nic nie opłaca, lepiej zrobić śliwowicę".

Marnotrawstwo dla wielu sadowników zdaje się być zaprzeczeniem wartości. David Graeber wskazuje na powiązanie między tylko pozornie niezależnymi aspektami ludzkiego życia - ekonomicznym pojęciem „wartość" a socjologicznym i filozoficznym rozumieniem „wartości” (Graeber 2005: 439). W języku polskim antonimem do słowa „marnotrawstwo” jest między innymi „oszczędność” i ,gospodarność”. Odruchowo kojarzymy marnotrawstwo z nieekonomicznym, nieracjonalnym działaniem. I rzeczywiście, ludzie bardzo często podejmując decyzje dotyczące sadów (i gospodarstw rolniczych, por. Krzyworzeka 2014), kierują się wartością ekonomicznego maksymalizowania zysków, jednak niekiedy to za mało, by w pełni zrozumieć proces podejmowania decyzji. 
Granice nielegalności. Śliwowica łącka w perspektywie antropologicznej

„Związek aksjologiczny ekonomicznej «wartości» z «wartościami» moralnymi pomaga zrozumieć, dlaczego w swoich działaniach gospodarczych ludzie nie kierują się - nie mogą się kierować - jedynie przesłankami natury ekonomicznej" (tamże). Wartość bowiem jest wyznaczana nie tylko za pomocą sił rynkowych, ale również poprzez różnego rodzaju procesy i zjawiska pozaekonomiczne.

Jednym z powodów, dla których śliwki pakuje się do beczek, jest chęć wykorzystania owoców, które nie nadają się do sprzedaży detalicznej i zminimalizowanie strat. Przekonanie o konieczności wykorzystania owoców stale pojawiało się w rozmowach, które prowadziłam. Pan Marek, sadownik zaangażowany przede wszystkim w uprawę jabłoni, twierdził, że ,jeśli śliwka ma się zmarnować, to lepiej przerobić ją na śliwowicę. To jest pożyteczne, bo i towar się nie zepsuje, i jest dobry dla zdrowia". Śliwowicę pędzi się również wtedy, gdy należy jakoś zagospodarować nadwyżkę owoców, które w przeciwnym razie mogłyby się zepsuć. Śliwki są bowiem znacznie trudniejsze do przetworzenia niż dominujące w łąckich sadach jabłka. Marnotrawienie owoców jest zaprzeczeniem wartości postrzeganej także w kategoriach moralnych. Społecznie pożądane jest, by maksymalnie wykorzystywać posiadane zasoby (śliwki), a zarazem nie marnotrawić poświęconego na pracę czasu (który niepostrzeżenie łączy się z życiem rodzinnym i relacjami z sąsiadami, znajomymi) i włożonego w nią wysiłku (obolałego ciała, wstawania nad ranem po to, by podlać zagrożone suszą drzewa). Śliwowica łącka jest zaprzeczeniem marnotrawstwa dzięki swojej wartości użytkowej (smak, efekt upojenia) i wymiennej.

\section{Dystrybucje}

W latach sześćdziesiątych minionego wieku Fredrik Barth (1967) opisał praktyki gospodarcze Furów w Darfurze, wskazując na istnienie dwóch sfer ekonomicznych. Sfery te to odrębne pola wymiany, które zawierają określone przedmioty lub usługi, w tym także środki pieniężne. W ramach pierwszej sfery nie dochodzi do przepływu pieniędzy - to praca i piwo podlegają wymianie. Druga z kolei opiera się na środkach pieniężnych, dzięki którym można nabyć określone przedmioty dostępne na lokalnych targach. Obie sfery podlegają sankcjom, moralnemu potępieniu, jednak drobna modyfikacja dotychczasowego modelu wymiany może zmienić 
status transakcji. Barth dostrzega w praktykach ekonomicznych pewną powtarzalność, na podstawie której tworzy model operowania zasobami przez lokalną społeczność.

Choć istnieje przynajmniej kilka kanałów dystrybucji śliwowicy łąckiej, można przyjąć, że funkcjonują one w ramach dwóch sfer ekonomicznych. Pierwsza z nich oparta jest na wzajemności, a transakcje, które są zawierane $\mathrm{w}$ jej ramach, zorientowane są na podtrzymywanie relacji społecznych. Już na wstępie wymagają pewnej dozy zaufania oraz odpowiedniej wiedzy, która umożliwia pomyślny przebieg transakcji. Większość dokonywanych w tej sferze transakcji opiera się na wymianie śliwowicy łąckiej w zamian za jaką́s przysługę, choć nie można wykluczyć obrotu środkami pieniężnymi. Zwykle transakcję inicjuje osoba posiadająca śliwowicę, która zamierza przy jej użyciu „załatwić jakąś sprawę”. Druga sfera to przede wszystkim transakcje oparte na pieniądzach. Przeważnie dochodzi do nich między osobami z zewnątrz a posiadaczami śliwowicy, choć transakcji można również dokonać przy pomocy pośrednika. Wymianę inicjuje chcąca dokonać zakupu osoba z zewnątrz. Butelka alkoholu może zostać skonsumowana przez kupca, ale może również zostać przekazana dalej, na przykład w formie podarunku.

Modele tego rodzaju upraszczają złożoną rzeczywistość. W przedstawionym schemacie dostrzec można klasyczne opozycje antropologiczne: dar - towar, wzajemność - indywidualizm oraz swój - obcy. Zamierzam nieco osłabić przeciwstawny charakter opisanych sfer ekonomicznych, pokazując ,jak płynne stają się kategorie daru i towaru, gdy przedmioty w ciągu swojego «życia» wchodzą w różne relacje społeczne i z nich się wydostają" (Wilk, Cliggett 2011: 181). Nie można zatem traktować daru i towaru jako statycznych kategorii, niemniej można powiedzieć, że „ekonomiczna wymiana tworzy wartość” (Appadurai 1986: 3). Co więcej, zarówno w systemie wymiany towarowej, jak i w wymianie darów ludzie dążą do maksymalizacji zysku (Wilk, Cligget 2011: 181), chęć zysku jest bowiem nieodłącznym elementem zawieranych przez ludzi transakcji (Barth 1966). Tym, co ma je od siebie odróżniać, jest jakość (lub brak) relacji społecznych stwarzanych w wyniku wymiany.

Tymczasem śliwowica łącka podlegająca wymianie opartej na wzajemności nie daje się jednoznacznie skategoryzować. Według opowieści krążących wśród moich znajomych, śliwowicą można załatwić różne sprawy. Słyszałam o wizytach u lekarza, niespodziewanej konfrontacji z policją, prezentach, drobnych upominkach i spotkaniach z tzw. elitą, 
Granice nielegalności. Śliwowica łącka w perspektywie antropologicznej

ale nigdy nie były to sytuacje realnie osadzone w czasie i przestrzeni. Praktyka załatwiania spraw za pomocą butelki alkoholu sięga zresztą czasów PRL-u (por. Wedel 2007, Dunn 2008), z tą różnicą, że wówczas za pędzenie śliwowicy karano. Mające monopol na produkcję alkoholu państwo ludowe nie wyrażało zgody na indywidualną działalność gorzelniczą. $\mathrm{Z}$ tego też względu ludzie chowali przed milicją sprzęt potrzebny do destylacji w okolicznych lasach, gdy „dostawali cynk” od znajomych lub krewnych. Takie naloty nie zdarzały się codziennie, niemniej obawa przed konfiskatą sprzętu była nieodłącznym elementem działalności bimbrowniczej. Dzisiaj do takich sytuacji raczej nie dochodzi, co jest w dużej mierze wynikiem społecznej legalności śliwowicy oraz ekonomicznego i politycznego klimatu panującego w danym momencie historycznym (Hann 2017: 124). Nadal jednak istnieje przekonanie o tym, że warto mieć śliwowicę w bagażniku samochodu lub w domu, tak na wszelki wypadek.

Trudno uznać tę przezorność za przypadek. Przyjęcie daru „narzuca konieczność ofiarowania czegoś w zamian" (Wilk, Cliggett 2011: 178), jest zobowiązaniem do wzajemności, nawet jeśli jest ona odroczona w czasie. Dawanie i przyjmowanie prezentów tworzy, podtrzymuje i wzmacnia relacje społeczne - śliwowica łącka będąca upominkiem dla krewnych, znajomych lub nowo poznanych osób nie pozostawia co do tego wątpliwości. Co jednak zrobić w przypadku, gdy śliwowica znajduje się w szarej strefie, gdzieś pomiędzy darem a towarem (zob. Yan 2005)? Załatwianie spraw przy użyciu butelki bimbru sprawia, że darowany alkohol zyskuje znamiona towaru, jednocześnie stając się rodzajem waluty. W artykule dotyczącym węgierskiej pálinki Chris Hann zastanawia się, dlaczego ma ona mniejsze znaczenie jako dar/łapówka dla urzędników niż w innych krajach postsocjalistycznych (2017). Tym samym zwraca uwagę na to, jak niezwykle trudnym zadaniem jest odróżnienie prezentu od przekupstwa ze względu na charakter wymiany, która polega na pozyskaniu trudno dostępnych usług i towarów (por. Humphrey 2010). Taka wymiana, jeśli ma zakończyć się sukcesem, wymaga subtelnej wiedzy lokalnej (Hann 2017: 120).

Michał Buchowski opisując doświadczenie mieszkańców wielkopolskiej wsi zwraca uwagę, że ,strategie przetrwania są [...] mechanizmami obronnymi społeczności, jej segmentów i poszczególnych osób w obliczu niezależnych od nich bezpośrednio czynników strukturalnych. Ich elementami są między innymi wszelkie sposoby na omijanie prawa czy wykorzystywanie luk w przepisach dla realizacji własnych interesów" 
(1996: 17). Omijanie prawa zawsze jest rezultatem sprawczości poszczególnych aktorów społecznych. Obdarowywanie śliwowicą łącką w zamian za różnego rodzaju przysługi jest moim zdaniem jedną z lokalnych strategii radzenia sobie w pełnej przypadkowych zdarzeń codzienności. O tym fenomenie pisała między innymi Janine R. Wedel w Prywatnej Polsce - „Polacy uczą się «załatwiać sprawy» (zdobywać towary i usługi oferowane $\mathrm{w}$ ramach formalnych struktur, często nieformalnymi sposobami). [...] Nabycie mebli, znalezienie opiekunki do dziecka, kupienie palta, zdobycie mieszkania czy zapewnienie sobie awansu to wszystko są sprawy do załatwienia” (2007: 74). Choć „załatwianie spraw” odnosi się przede wszystkim do czasu sprzed transformacji ustrojowej, to określenie to nadal funkcjonuje w języku polskim i - co istotne - ma realny związek z praktyką społeczną.

Szczególny rodzaju daru będący pośrednią formą w pozornie przeciwstawnej relacji dar-towar opisuje Yunxiang Yan (2005: 256). Mowa o darze instrumentalnym (instrumental gift), który w Chinach wręczany jest w zamian za przysługi oraz usługi - osoby, które je przyjmują, zobowiązane są odwdzięczyć się poprzez wykorzystanie swojej pozycji lub zapewnienie zasobów, które znajdują się pod ich kontrolą (tamże). Praktyka załatwiania spraw odnosi się do podobnych układów i relacji władzy. Przeważnie załatwiamy sprawy z ludźmi, którzy mają dostęp do rzeczy lub przywilejów dla nas z różnych względów niedostępnych. Niestety, przymiotnik ,instrumentalny” może wprowadzić czytelnika w błąd - nasuwa bowiem skojarzenie z transakcją, w której nie ma miejsca na relacje wzajemności. Tymczasem, jak wskazuje Hann, wzajemność jest jak najbardziej kompatybilna z gospodarką rynkową - jako przykład podaje powiązania rynkowe funkcjonujące dzięki ewoluującemu zaufaniu między producentami a ich klientami (2017: 120). Instrumentalność daru nie wyklucza zatem wymiany opartej na wzajemności.

Załatwianie spraw poprzez znajomości jest polskim wariantem fenomenu, który historyk Harry Liebersohn (2011) określa mianem ekonomii przysług (economy of favours). Zjawisko to obejmuje głęboko zakorzenione doświadczenie socjalizmu i gospodarki niedoboru, a jego analizę dodatkowo komplikuje lokalny kontekst historyczny - czym innym będzie opisywane przez Wedel załatwianie spraw w Warszawie w latach osiemdziesiątych, czym innym zaś w Łącku w drugiej dekadzie XXI wieku. Mają one jednak wspólny mianownik - określenie „,załatwić sprawę”, jak pisze Wedel, „może odnosić się aluzyjnie do nie- 
Granice nielegalności. Śliwowica łącka w perspektywie antropologicznej

mal każdej kwestii. Jeśli mówię komuś, że mam sprawę do załatwienia i muszę się pożegnać, nie muszę wdawać się w szczegóły. Sprawa może być zupełnie banalna lub legalna, ale rzecz w tym, że nikt nie wie, czy w rzeczywistości nie chodzi o jakieś krętactwo" (2007: 75). Kiedy moi znajomi opowiadali o załatwianiu spraw przy pomocy butelki śliwowicy, nie musieli niczego thumaczyć, bowiem język pozwala na pominięcie szczegółów transakcji. Muszę jednak zaznaczyć, że sama nigdy nie byłam świadkiem takiej transakcji, a jedynie o nich słyszałam - co więcej, trudno stwierdzić, czy świadkami takiej wymiany byli moi znajomi. Kluczowe jest jednak to, że istnieje powszechne przekonanie o tym, że dzięki śliwowicy łąckiej można sobie ułatwić życie lub uchronić się przed kłopotami.

\section{Praktykowanie nielegalności}

Kupno nielegalnie pędzonej śliwowicy łąckiej jest niezwykle kuszącą wizją dla turystów żądnych wrażeń i autentycznego doświadczenia lokalnej tradycji (por. Handler, Linnekin 1984; Hobsbawm, Ranger 2008). Transakcje planowane i realizowane są w aurze tajemniczości charakterystycznej dla robienia czegoś poza granicami prawa, niezależnie od istniejącego wśród lokalnych strażników prawa przyzwolenia na produkcję. Zakaz produkcji oraz dystrybucji destylatów, który obowiązuje w Polsce, jest bowiem przez wielu uważany za fikcję i absurd. Jak powtarzał pracownik lokalnego sklepu spożywczego: „ludzie chcą śliwowicy od chłopa”. I rzeczywiście, wielu ludzi dokonuje zakupu łąckiej śliwowicy przy pomocy poczty pantoflowej oraz przez lata wypracowanych kontaktów, a osoby sprzedające śliwowicę zwykle nie ponoszą prawnych konsekwencji. Pozostaje pytanie - moim zdaniem jak najbardziej zasadne - dlaczego śliwowica łącka jest obiektem pożądania turystów? Istnieje wiele przesłanek, by sądzić, że w dużej mierze to nielegalność śliwowicy jest odpowiedzialna za jej popularność.

Według opisu, który znajd je się na stronie Ministerstwa Rolnictwa i Rozwoju Wsi, już w XVII i XVIII wieku w Łącku istniały liczne sady śliw i jabłoni. Przypuszczalnie część owoców przeznaczona była na produkcję śliwowicy. Jednak nieoficjalny charakter bimbrowniczej działalności sięga, moim zdaniem, XIX-wiecznej produkcji śliwowicy pejsecznej. W 1875 roku ziemię łącką nabył żydowski przemysłowiec, 
Michał Ader, który rozwinął miejscowe zakłady przetwórstwa owoców, w tym także produkcję śliwowicy łąckiej. Obowiązywało wówczas prawo propinacji, które w Łącku przysługiwało Żydom: tylko oni mieli oficjalne pozwolenie na sprowadzanie i sprzedaż napojów alkoholowych. Prawo wytworzyło sytuację, w której chłopi mogli spożywać alkohol dostępny i sprzedawany jedynie w karczmach (zob. Burszta 1950, 1951). Ograniczenia wynikające $\mathrm{z}$ takich regulacji prawnych stworzyły niszę $\mathrm{w}$ postaci wytwarzania alkoholu na własną rękę, poza zasięgiem wzroku propinatora. Nielegalny charakter bimbrowniczej działalności związany był prawdopodobnie z rozwojem sadownictwa, obowiązującą propinacją oraz tworzeniem się państwa w XIX wieku, które formułowało określone ramy prawne dla przemysłu związanego z produkcją alkoholu.

Później, już po zakończeniu II wojny światowej, miejscowa ludność nadal zmagała się z ambiwalentnym stosunkiem władz do produkcji śliwowicy. Z jednej strony, stołując się w regionalnych restauracjach, można było napić się łąckiego trunku, a butelki wystawiano podczas istniejącego od lat czterdziestych Święta Kwitnącej Jabłoni. Wstępnie wyrażono też wówczas zgodę na budowę fabryki śliwowicy. Pan Franciszek, jeden z sadowników, opowiadał mi, że w latach siedemdziesiątych, w ramach zajęć technicznych, on i jego koledzy robili przy użyciu metody linorytu etykiety na butelki. Co więcej, jak wspominają miejscowi,

szczególnym wzięciem śliwowica cieszyła się w latach 70., kiedy za butelkę „łąckiej" można było załatwić niemal wszystko. To czasy reformy administracyjnej, która miała zdecydować, czy nowe województwo, obejmujące m.in. Tatry, Gorce i Beskid Sądecki, będzie miało stolicę w Nowym Targu, czy Nowym Sączu. A że z Łącka bliżej do tego drugiego miasta... (Kuraś 2012).

Z drugiej strony, podczas kontrolnych nalotów milicji konfiskowano lub niszczono wyprodukowany alkohol (np. poprzez zanieczyszczenie go) oraz, znacznie częściej, sprzęt do destylacji.

Po transformacji ustrojowej podejmowano kolejne próby zmiany prawa, które miały doprowadzić do legalizacji. W latach dziewięćdziesiątych samorząd powołał spółkę z o.o. Łącko, która zwróciła się do Ministerstwa Rolnictwa z prośbą o umożliwienie produkcji. Niestety, ze względu na wciąż nierozwiązany prawny aspekt produkcji, ostatecznie do niczego nie doszło. 
Granice nielegalności. Śliwowica łącka w perspektywie antropologicznej

Od tego czasu każdy rząd obiecywał, że zalegalizuje śliwowicę. Najdalej poszedł minister Andrzej Śmietanko z PSL, który w 1995 roku, kilka dni przed ustąpieniem ze stanowiska, podpisał - wzorem innych krajów europejskich - koncesję na produkcję nalewek. W Łącku już się cieszyli, przygotowywano się nawet do wypuszczenia akcji. Przedwcześnie. Bo kolejny minister nie wprowadził w życie aktów wykonawczych do decyzji swego poprzednika (Kuraś 2012).

Obserwując zmieniające się na przestrzeni dekad realia polityczno-gospodarcze i stosunek władz do śliwowicy, trudno nie zauważyć silnego związku alkoholu z państwem oraz obowiązującym w jego ramach prawem. Podlegający dynamicznym przemianom ekonomiczny i polityczny klimat wpływa między innymi na koszty produkcji, ryzyko bycia złapanym, charakter potencjalnej kary oraz przychylność (lub jej brak) lokalnej społeczności (Hann 2017: 124). Tymczasem niezależnie od tego, jakie jest oficjalne stanowisko władz w sprawie śliwowicy i alkoholu w ogóle, miejscowa ludność rokrocznie napełnia beczki śliwkami. Zmieniają się zatem okoliczności, w jakich produkowana jest śliwowica, jednak praktyka pozostaje ta sama.

Przypadek śliwowicy łąckiej funkcjonuje w odniesieniu do opozycji pomiędzy tym, co legalne i nielegalne, przy czym status ten nigdy nie jest jednoznaczny. Podlega ciągłej dynamice społecznej i zależy od interesów konkretnych aktorów społecznych - od państwa i gminy po poszczególne jednostki. Jestem zdania, że przypisywanie statusu nielegalności określonym produktom lub działalności powinno być postrzegane nie jako stan (status), a raczej jako proces wyrażany poprzez praktykę społeczną, jak ma to miejsce w przypadku tożsamości czy etniczności (zob. Ardener 1992; Astuti 1995; Barth 2004; Gow 2007). Postrzeganie legalności w kategoriach procesu sprawia, że to, czy coś jest nielegalne, przestaje być kwestią jednorazowego nadania statusu. Podobnie należy myśleć o śliwowicy łąckiej. Ostatecznie bowiem to, co według obowiązujących przepisów jest nielegalne, społecznie może być uznawane za legalne - tę pozorną sprzeczność określam praktykowaniem nielegalności.

W pracach z zakresu nauk społecznych pojawiają się obowiązujące w określonych ramach społeczno-kulturowych kategorie prawne, które jednocześnie służą badaczom jako kategorie analityczne. Funkcjonowanie w dyskursie naukowym binarnego podziału na nielegalny obieg towarów i oficjalne sieci dystrybucji prowadzi do używania w analizach społecznie konstruowanych wartości, które stoją za ekonomicznymi praktykami. 
W takim kontekście Daniel Miller proponuje pominąć rozbieżność między ekonomiczną ,wartością" ceny i etycznie postrzeganymi „wartościami” (za: Panella, Thomas 2015: 5). Podobną refleksję znaleźć można, jak już wspomniałam, u Graebera (2005). Ponadto, choć studia nad nielegalnością z założenia są projektem interdyscyplinarnym, nadal nie jest powszechne rozróżnienie pomiędzy społeczną i polityczną konstrukcją legalności (Van Schendel, Abraham 2005). Rzadko również zwraca się uwagę na fakt, że nielegalne praktyki to ciągłe negocjowanie prawa, wartości i odpowiedzialności (Panella, Thomas 2015: 5). Tymczasem już w latach siedemdziesiątych Keith Hart zwrócił uwagę na korzyści istnienia gospodarki nieformalnej oraz na dialektykę i wzajemne powiązania pomiędzy różnymi typami gospodarki (1973). Hart „chciał przekonać ekonomistów zajmujących się rozwojem, by porzucili model «bezrobocia» i dostrzegli, że w «oddolnej» gospodarce (grassroot economy) działo się dużo więcej, niż pozwalała im dostrzec ich biurokratyczna wyobraźnia" (tamże: 136).

Sprawę dodatkowo komplikuje fakt, że prawo i polityka same w sobie są tworami społecznymi i uwarunkowanymi kulturowo. Nie jest zatem zadaniem prostym zrozumienie prawnie nielegalnej działalności, która w procesie historycznym zyskała społeczną akceptację, także wśród przedstawicieli formalnie należących do porządku państwa. Wielu badaczy wskazuje na niestabilny charakter legalności i nielegalności (zob. Nordstrom 2007), który jest efektem nie tyle regulacji prawnych, ile społecznych wyobrażeń na ten temat oraz możliwych strategii zaprzeczania, unikania lub wzmacniania tego podziału (Thomas, Galemba 2013: 211). Jak wskazują Panella i Thomas, „kategoryzacje, takie jak etyczne/nieetyczne i legalne/ nielegalne, oznaczają coś nie tylko poprzez oficjalne akty i oświadczenia, ale raczej przez nagromadzone, powszechne interakcje ludzi, dla których te określenia mają szczególne znaczenie" (2015: 6). Co więcej, rozpatrywanie poszczególnych przypadków, w tym także sposobów postrzegania prawnych kategorii przez tubylców, powinno iść w parze $\mathrm{z}$ refleksją nad tym, jaką rolę w nielegalnych praktykach odgrywa państwo. Przypadek śliwowicy łąckiej utwierdza w przekonaniu, że usankcjonowana przez państwo opozycja legalne - nielegalne jest niewystarczająca do tego, by zrozumieć oraz opisać absurdy i napięcia, które są wynikiem nie tyle rozporządzeń prawnych, ile ich praktykowania. Według niektórych badaczy kategorie prawne tego rodzaju nie są użyteczne w przypadku społeczeństw pozbawionych struktur państwowych (Hartnett, Dawdy 2013: 32). Moim 
Granice nielegalności. Śliwowica łącka w perspektywie antropologicznej

zdaniem, należy zachować sceptycyzm także wobec swobodnego wykorzystywania kategorii legalne/nielegalne w stosunku do społeczeństw funkcjonujących w ramach państw narodowych.

Oficjalna polityka państwa w większości przypadków opisuje nielegalne praktyki jako pozbawione wartości moralnych, nieefektywne i zagrażające narodowi (Panella, Thomas 2014: 3). Zdawać by się mogło, że również śliwowica łącka jako produkt nielegalny będzie podlegała krytyce państwa, tymczasem sytuacja jest znacznie bardziej skomplikowana. Choć antropolodzy nagminnie odkrywają, że „niektórzy obywatele mniej chętnie niż inni akceptują oficjalnie usankcjonowane normy kulturowe i prawne" (Herzfeld 2007: 13), w polskiej antropologii nadal nie stanowi to szczególnego przedmiotu zainteresowania (między innymi za wyjątkiem: Rakowski 2009). Co więcej, często zapomina się o tym, że do grona obywateli należą również urzędnicy państwowi, policjanci i inne osoby lub grupy, które w swoich pracach opisujemy jako „elity”. Tymczasem Herzfeld zwraca uwagę, że taki upraszczający rzeczywistość podział na elity i zwykłych ludzi ,,przesłania wspólne podłoże (podobnie jak fakt, że same w sobie te terminy są często instrumentami w negocjowaniu stosunków władzy), a przez to utrudnia analizę" (tamże: 15).

Śliwowica łącka nie tylko nie podlega krytyce, ale jest stale wspierana i wykorzystywana przez instytucje państwowe oraz samorządowe, między innymi w celu promowania regionalności/lokalności (za pomocą festiwali - Święta Kwitnącej Jabłoni, Święta Owocobrania - oraz poprzez wpisanie regionalnych produktów na listę produktów tradycyjnych, listę niematerialnego dziedzictwa kulturowego i zastrzeżenie ich jako znaki towarowe w Urzędzie Patentowym). Można to tłumaczyć między innymi tym, że promocja jest dziś ważnym narzędziem w procesie pozyskiwania kapitału na całym świecie, a punktem odniesienia i narzędziem w walce o kapitał stały się regionalizm i lokalność, promocja regionalna wynika zaś ze specyficznej artykulacji lokalnej tradycji (Clifford 2011, Demossier 2010). Śliwowica łącka jest reprezentacją regionalności/lokalności i na pewnym poziomie to właśnie wspierany instytucjonalnie nielegalny status uzasadnia jej istnienie.

Paradoksalnie zatem, czarny rynek to zatem nie tylko praktyki zagrażające państwu, lecz również wspierające państwo narodowe. Ostatecznie nielegalne praktyki zawsze bowiem powiązane są z „formalnymi ekonomiami i legalnymi praktykami konsumenckimi" (Panella, Thomas 2005: 6). Według Herzfelda antropolodzy powinni poszukiwać „wzajemnych 
związków między oficjalnym państwem a niekiedy destrukcyjnymi, powszechnymi praktykami, których istnieniu ono często zaprzecza, ale których żywotność jest ironicznym warunkiem jego trwania" (2007: 17). Co prawda trudno uznać produkcję i dystrybucję śliwowicy łąckiej za destrukcyjną praktykę, ale trudno też stwierdzić, że państwo polskie zaprzecza jej istnieniu. Jest wręcz przeciwnie - państwo wykorzystuje istnienie śliwowicy do tego, by uzasadniać swoją odrębność i wyjątkowość w stosunku do innych. Na niższych szczeblach schemat jest podobny - województwo małopolskie wykorzystuje łącki trunek do promocji w kategorii „najbardziej atrakcyjnego województwa”, a gmina Łącko wykorzystuje śliwowicę do promocji w kategorii „,najbardziej atrakcyjnej gminy”. Jednocześnie należy pamiętać, że „za każdym jego [państwa, województwa, gminy] przywołaniem czają się pragnienia i plany ludzi z krwi i kości" (tamże).

\section{Podsumowanie}

Szczególny związek alkoholu i państwa już dawno został dostrzeżony przez antropologów i historyków. Marion Demossier pisze o kulturze picia wina we Francji jako pewnym micie narodowym (2010), z kolei Chris Hann pokazuje, jak zmienił się status pálinki, która obecnie jest jednym z kluczowych składników węgierskiego dziedzictwa narodowego. Pozwala to przypuszczać, że trunek ten zachowa swoje znaczenie, pozostając poza rynkiem]i prawem państwowym (2017: 123). W podobnym tonie pisze amerykańska antropolożka, Nancy Ries (2009), która rolę kartoszki (ziemniaka) w kulturze rosyjskiej interpretuje jako rodzaj kulturowej ontologii alkoholu (potato ontology). W tym ujęciu ziemniak i produkty z niego powstające nie tylko pomagają konceptualizować postsocjalistyczną rzeczywistość, ale odgrywają kluczową rolę w kształtowaniu i utrzymywaniu tego świata (tamże: 183). Przypadek śliwowicy wpisuje się w ramy ścisłych relacji pomiędzy państwem a praktykami związanymi z alkoholem, będąc produktem wielu polityk, między innymi współcześnie dominującej polityki dziedzictwa kulturowego.

Tymczasem ostatecznie okazało się, że zamiast zetknąć się z epatowaniem lokalnością (którego najwidoczniej się spodziewałam), spotykałam ludzi, którzy codziennie pracują lub mają „dużo rzeczy do roboty”. Sadownictwo, aktualnie panująca pogoda, owoce, a przede wszystkim 
Granice nielegalności. Śliwowica łącka w perspektywie antropologicznej

jabłka, transporty owoców do pobliskich hurtowni lub dalej, do Nowego Sącza czy do Nowego Targu, zajmowanie się wnukami, przygotowywanie posiłków, praca $\mathrm{w}$ firmach i instytucjach oddalonych o kilkanaście lub kilkadziesiąt kilometrów od miejsca zamieszkania - to była codzienność zajmująca moich gospodarzy, pracodawców i ich rodziny. Wśród codziennych aktywności, śliwowica łącka zdecydowanie znajduje się na dalszym planie, nie stanowi centrum zainteresowania żadnej z osób, z którą przyszło mi współpracować. Nawet pan Jerzy czy Krzysztof Maurer, którzy robią własną śliwowicę, nie organizują swojej pracy wokół tego produktu. Znacznie ważniejsze są owoce, przede wszystkim jabłka, które cieszą się większą popularnością i są łatwiejsze w obróbce niż śliwki. Z tego też względu Krzysztof Maurer największą uwagę poświęca tłoczeniu soków owocowych, natomiast pan Jerzy jeździ z owocami do hurtowni i skupów, na przykład do Nowego Sącza. Śliwowica jest raczej produktem ubocznym uprawy drzew owocowych.

Wśród moich terenowych towarzyszy większą popularnością cieszy się piwo i wódka, często podawana w formie drinków z dodatkiem napojów owocowych bądź gazowanych. Śliwowica jest produktem przeznaczonym przede wszystkim dla osób z zewnątrz. Nie wyklucza to oczywiście spożywania śliwowicy przez jej wytwórców, ich rodzin, przyjaciół czy znajomych. Opowiadano mi o weselach, na których śliwowica stoi tuż obok wódki. Pojawia się także na imprezach - zarówno masowych, takich jak Święto Owocobrania, jak i podczas spotkań w kameralnym gronie. Dominuje jednak przeświadczenie, że śliwowica jest produktem regionalnym, którego dystrybucja może przyczynić się do promocji Łącka i okolic, a tym samym jego rozwoju gospodarczego. Śliwowicę kupować mają przede wszystkim turyści lub osoby, które mogą zachęcić innych do wypoczynku w Łącku - to zresztą tłumaczy niechęć tubylców do podrabianej śliwowicy. Jednocześnie śliwowica podlega nieformalnej wymianie za różnego rodzaju usługi. Taka wymiana wymaga wcześniej zbudowanego zaufania oraz wiedzy, która umożliwia korzystny dla obu stron przebieg transakcji. Jak starałam się pokazać, o ile śliwowica rozumiana jako produkt regionalny reklamujący Łącko i okolice jest towarem, o tyle w lokalnej wspólnocie pełni przede wszystkim rolę daru.

Jednocześnie, praktykowanie nielegalności odbywa się na wielu poziomach oraz uwikłane jest $\mathrm{w}$ różnego rodzaju publiczne oraz prywatne interesy polityczne i ekonomiczne, do tego stopnia, że de facto trudno mówić o rozdzieleniu obu tych sfer. Śliwowica łącka jest ujęta w ramy 
prawne poprzez uznanie jej za niematerialne dobro kultury, wpisanie na ministerialną listę produktów tradycyjnych oraz zastrzeżenie znaku towarowego. To oznacza, że nielegalnie produkowany alkohol może być przedmiotem sporu o charakterze prawnym w przypadku wykorzystania znaku towarowego przez podmioty, które nie uzyskały oficjalnego pozwolenia. Przypadek śliwowicy łąckiej potwierdza, że praktyki w świetle prawa uznawane za nielegalne, w perspektywie antropologicznej należy rozpatrywać w dynamicznych kategoriach dialektyki legalnego z nielegalnym. Do tego niezbędna jest baczna obserwacja zależności i relacji pomiędzy różnymi skalami - od jednostek, rodzin i stowarzyszeń, poprzez władze samorządowe i rządowe, aż po międzynarodowe organizacje.

\section{BIBLIOGRAFIA}

Appadurai A. (1986). Commodities and the Politics of Value. W: Tenże. The social life of things, s. 3-63. Cambridge: Cambridge University Press.

Ardener E. (1992). Tożsamość i utożsamienie (przeł. Z. Mach). W: Z. Mach, A. K. Paluch (red.). Sytuacja mniejszościowa i tożsamość, s. 21-42. Kraków: Wydawnictwo Uniwersytetu Jagiellońskiego.

Astuti R. (1995). "The Vezo Are Not a Kind of People". Identity, Difference, and "Ethnicity" among a Fishing People of Western Madagascar. American Ethnologist Vol. 22, 464-482.

Barth F. (1966). Models of Social Organization. London: Royal Anthropological Institute of Great Britain and Ireland.

Barth F. (1967). Economic spheres in Darfur. W: R. Firth (red.). Themes in economic anthropology, s. 149-174. London: Tavistock.

Barth F. (2004). Grupy i granice etniczne (przeł. M. Głowacka-Grajper). W: M. Kempny, E. Nowicka (red.). Badanie kultury. Elementy teorii antropologicznej. Kontynuacje, s. 348-377. Warszawa: Wydawnictwo Naukowe PWN.

Buchowski M. (1996). Klasa i kultura w okresie transformacji. Antropologiczne studium przypadku społeczności lokalnej w Wielkopolsce. Poznań: Drawa.

Burszta J. (1950). Wieś i karczma. Rola karczmy w życiu wsi pańszczyźnianej. Warszawa: Ludowa Spółdzielnia Wydawnicza.

BursztaJ.(1951).Spoleczeństwoikarczma.Propinacja,karczmaisprawaalkoholizmu w społeczeństwie polskim XIX wieku. Warszawa: Ludowa Spółdzielnia Wydawnicza. 
Granice nielegalności. Śliwowica łącka w perspektywie antropologicznej

Carrier J. G. (red.) (2005). A Handbook of Economic Anthropology. London: Edward Elgar Publishing Ltd.

Cash J. (2015). Economy as Ritual. The problems of Paying in Wine. W: S. Gudeman, Ch. Hann (red.). Economy and Ritual. Studies of Postsocialist Transformations, s. 31-51. New York and Oxford: Berghahn.

Clifford J. (2001). Indigenous Articulations. The Contemporary Pacific Vol. 13, 468-490.

Demossier M. (2010). Wine drinking culture in France. A national myth or a modern passion? Cardiff: University of Wales Press.

Dunn E. (2008). Prywatyzujac Polskę. O bobofrutach, wielkim biznesie i restrukturyzacji pracy (przeł. P. Sadura). Warszawa: Wydawnictwo Krytyki Politycznej.

Favret-Saada J. (2012). Śmiercionośne słowa, zabójcze uroki (przeł. K. Marczewska). Warszawa: Oficyna Naukowa.

Gow P. (2007). "Ex-Cocama". Transforming Identities in Peruvian Amazonia. W: C. Fausto, M. Heckenberger (red..). Time and Memory in Indigenous Amazonia. Anthropological Perspectives, s. 194-215. Gainesville: University Press of Florida.

Graeber D. (2005). Value: anthropological theories of value. W: J G. Carrier(red.). A Handbook of Economic Anthropology, s. 439-454. London: Edward Elgar Publishing Ltd.

Handler R., Linnekin J. (1984). Tradition, Genuine or Spurious. The Journal of American Folklore Vol. 97, 273-290.

Hann Ch. (2017). The Human Economy of Pálinka in Hungary. A Case Study in Longue Duré Lubrication. W: D. Henig, N. Makovicky (red.), Economies of Favour after Socialis, s. 117-139. Oxford University Press.

Hart K. (1973). Informal income opportunities and urban employment in Ghana. Journal of Modern African Studies Vol. 11 (1), 61-89.

Hartnett A., Dawdy S. L. (2013). The Archaeology of Illegal and Illicit Economies. Annual Review of Anthropology Vol. 42, 37-51.

Herzfeld M. (2007). Zażytość kulturowa. Poetyka spoteczna w państwie narodowym (przeł. M. Buchowski). Kraków: Wydawnictwo Uniwersytetu Jagiellońskiego.

Hobsbawm E., Ranger T. (red.). (2008). Tradycja wynaleziona (przeł. M. Godyń, F. Godyń). Kraków: Wydawnictwo Uniwersytetu Jagiellońskiego.

Humphrey C. (2010). Koniec radzieckiego życia. Ekonomie życia codziennego po socjalizmie (przeł. A. Halemba). Kęty: Wydawnictwo Marek Derewiecki. 
Krzyworzeka A. (2014). Rolnicze strategie pracy i przetrwania. Studium z antropologii ekonomicznej. Warszawa: Wydawnictwo Uniwersytetu Warszawskiego.

Kuraś B. (2012). Pierwszy łyk legalnej śliwowicy. Wkrótce dystrybucja. Gazeta Wyborcza. Pobrano z: http://wyborcza.pl/1,76842,12801174,Pierwszy_ lyk_legalnej_sliwowicy_Wkrotce_dystrbucja.html.

Kuraś B. (2012). Śliwowica z Łącka. Perypetie z legalizacją słynnego trunku. Gazeta Wyborcza. Pobrano z: http://krakow.wyborcza.pl/krakow/1,44425,12821659,Sliwowica_z_Lacka_Perypetie_z_legalizacja_slynnego.html.

Liebersohn H. (2011). The Return of the Gift: European history of a global idea. Cambridge: Cambridge University Press.

Łącka Śliwowica. Wspólny Znak Towarowy Gwarancyjny. (2012). Pobrano z: http://www.ldo.pl/sliwowica.pdf.

Nordstrom C. (2007). Global Outlaws: Crime, Money, and Power in the Contemporary World. Berkeley: University of California Press.

Panella C., Thomas K. (2015). Ethics, evaluation, and economies of value amidst illegal practices. Critique of Anthropology Vol. 35, 3-12.

Rakowski T. (2009). Łowcy, zbieracze i praktycy niemocy. Etnografia człowieka zdegradowanego. Gdańsk: Wydawnictwo Słowo/Obraz Terytoria.

Ries N. (2009). Potato Ontology: Surviving Postsocialism in Russia. Cultural Anthropology Vol. 24, 181-212.

Rogers D. (2005). Moonshine, money, and the politics of liquidity in rural Russia. American Ethnologist Vol. 32, 63-81.

Śliwowica łącka. (2005). Pobrano z: https://www.gov.pl/rolnictwo/sliwowica-acka.

Święto Kwitnącej Jabłoni. Pobrano z: http://www.lacko.pl/swieto-kwitnacej-jabloni.html.

Święto Owocobrania. Pobrano z: http://www.lacko.pl/swieto-owocobrania.html.

Thomas K., Galemba R. B. (2013). Illegal Anthropology: An Introduction. PoLAR: Political and Legal Anthropology Review Vol. 36, 211-214.

Tłocznia Maurer. Pobrano z: https://www.sklepmaurera.pl/19-destylaty\#/smak-sliwkowy.

Ustawa z dnia 2 marca $2001 \mathrm{r}$ o wyrobie alkoholu etylowego oraz wytwarzaniu wyrobów tytoniowych. (2001). Pobrano z: http://prawo.sejm.gov.pl/isap. nsf/DocDetails.xsp?id=WDU20010310353.

Van Schendel W., Abraham I. (red.). (2005). Illicit Flows and Criminal Things: States, Borders, and the Other Side of Globalization. Indianapolis: University of Indiana Press. 
Granice nielegalności. Śliwowica łącka w perspektywie antropologicznej

Wedel J. R. (2007). Prywatna Polska (przeł. S. Kowalski). Warszawa: Trio.

Wilk R. R., Cliggett L. (2011). Ekonomie i kultury. Podstawy antropologii ekonomicznej (przeł. J. Gilewicz). Kraków: Wydawnictwo Uniwersytetu Jagiellońskiego.

Yan Y. (2005). The gift and gift economy. W: J. G. Carrier (red.), A Handbook of Economic Anthropology, s. 246-261. London: Edward Elgar Publishing Ltd. 